\title{
Cetacean sightings within the Great Pacific Garbage Patch
}

\author{
Susan E. Gibbs ${ }^{1} \cdot$ Chandra P. Salgado Kent $^{2,3,4} \cdot$ Boyan Slat $^{1} \cdot$ Damien Morales $^{1,5} \cdot$ Leila Fouda $^{1,6} \cdot$ Julia Reisser $^{7,8}$ (D)
}

Received: 12 July 2018 / Revised: 8 March 2019 / Accepted: 15 March 2019 / Published online: 9 April 2019

(C) The Author(s) 2019

\begin{abstract}
Here, we report cetacean sightings made within a major oceanic accumulation zone for plastics, often referred to as the 'Great Pacific Garbage Patch' (GPGP). These cetacean records occurred in October 2016 and were made by sensors and trained observers aboard a Hercules C-130 aircraft surveying the GPGP at $400 \mathrm{~m}$ height and 140 knots speed. Four sperm whales (including a mother and calf pair), three beaked whales, two baleen whales, and at least five other cetaceans were observed. Many surface drifting plastics were also detected, including fishing nets, ropes, floats and fragmented debris. Some of these objects were close to the sighted mammals, posing entanglement and ingestion risks to animals using the GPGP as a migration corridor or core habitat. Our study demonstrates the potential exposure of several cetacean species to the high levels of plastic pollution in the area. Further research is required to evaluate the potential effects of the GPGP on marine mammal populations inhabiting the North Pacific.
\end{abstract}

Keywords Marine debris $\cdot$ Marine mammals $\cdot$ Plastic pollution $\cdot$ Aerial survey

\section{Introduction}

Some plastics have the capacity to float at sea for extended periods of time and may accumulate in oceanic areas of the world's sea surface. These large accumulation zones formed within subtropical gyres are well known for their high levels of plastic pollution (Lebreton et al. 2012; Eriksen et al. 2014; Lebreton et al. 2018). However, the ecological implications of

Communicated by S. E. Lluch-Cota

Julia Reisser

jureisser@gmail.com

1 The Ocean Cleanup Foundation, Rotterdam, The Netherlands

2 Centre for Marine Science and Technology, Curtin University, Perth, Australia

3 Oceans Blueprint, Perth, Australia

4 Centre for Marine Ecosystems Research, Edith Cowan University, Perth, Australia

5 Blue Planet Marine, Canberra, Australia

6 School of Biological and Chemical Studies, Queen Mary University of London, London, UK

7 Minderoo Foundation, Perth, Australia

8 UWA Oceans Institute, University of Western Australia, Perth, Australia such pollution hotspots remain poorly assessed (Chen et al. 2017). For instance, no dedicated aerial surveys have been undertaken to record marine mammals within these areas and/or identify local impacts of plastic debris on vertebrates. Nonetheless, it is well known that ocean plastics pose a threat to marine mammals, with many cases of entanglement and ingestion interactions being recorded worldwide (Walker and Coe 1989; Laist 1997; Baulch and Perry 2014; Page et al. 2004; Fossi et al. 2012).

Here, we describe the first cetacean sightings made within the so-called Great Pacific Garbage Patch (GPGP; Kaiser 2010; Chu et al. 2015; Lebreton et al. 2018). This is an oceanic accumulation zone for floating debris located within the North Pacific subtropical gyre, about halfway between Hawaii and California. Our sightings occurred during an aerial survey in October 2016 that focused on characterising and quantifying ocean plastics through experienced observers and multiple types of sensors (Salgado Kent et al. 2017; Lebreton et al. 2018).

\section{Material and methods}

Using a Hercules C-130 aircraft, we conducted one trial flight to test the visual survey setup and calibrate sensors, followed by two survey flights. Both survey flights started and ended at 
Moffett Airfield, California, USA. The aircraft flew at high altitude and speed whilst in transit ( $3 \mathrm{~h}$ to/from survey sites), and at $\sim 400 \mathrm{~m}$ and $\sim 140$ knots ground speed during surveys. The first flight occurred on 2 October 2016, sampling from 18:56 to $21: 14$ UTC time, over a constant latitude of $33.5^{\circ} \mathrm{N}$ and longitudes from $141.4^{\circ} \mathrm{W}$ to $134.9^{\circ} \mathrm{W}$ (see map in Fig. 1). The second flight occurred on 6 October 2016, sampling from $22: 14$ to $0: 37 \mathrm{UTC}$, over a straight trajectory from $30.1^{\circ} \mathrm{N}$, $143.7^{\circ} \mathrm{W}$ to $32.9^{\circ} \mathrm{N}, 138.1^{\circ} \mathrm{W}$. Transects covered areas of the
GPGP where the predicted sea state conditions were the lowest, based on sea surface atmospheric pressure, cloud cover, wind speed (NOAA's Global Forecasting System), wave height and peak period (NOAA's WaveWatch3 model).

For the visual surveys, we had eight trained staff: four observers and four people recording sightings on laptops (called 'data recorders' hereafter). Observers were positioned in pairs on either side of the aircraft, facing directly out of open paratroop doors, as close to the aircraft edge as possible.

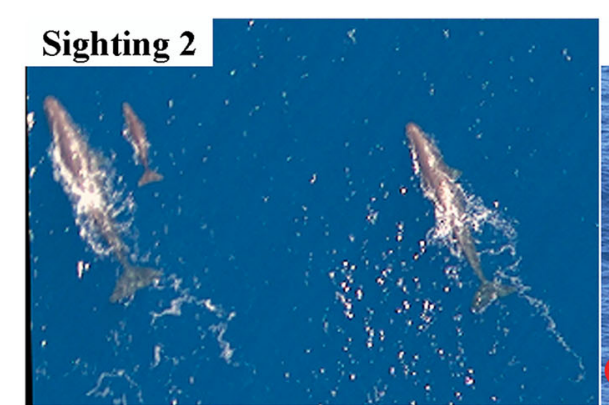

\section{Sighting 6 \\ Sighting 6}

\section{Sighting 3}

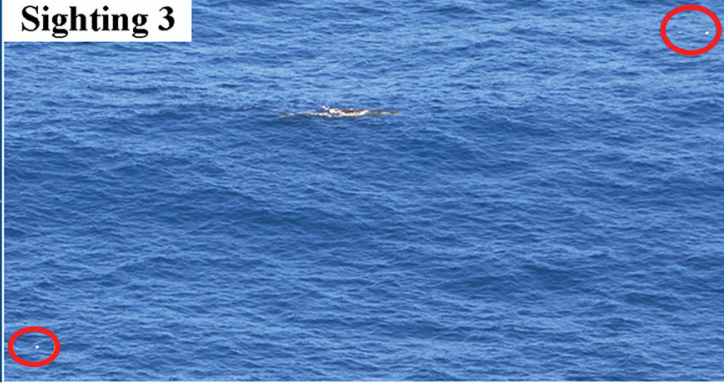

Sighting 7

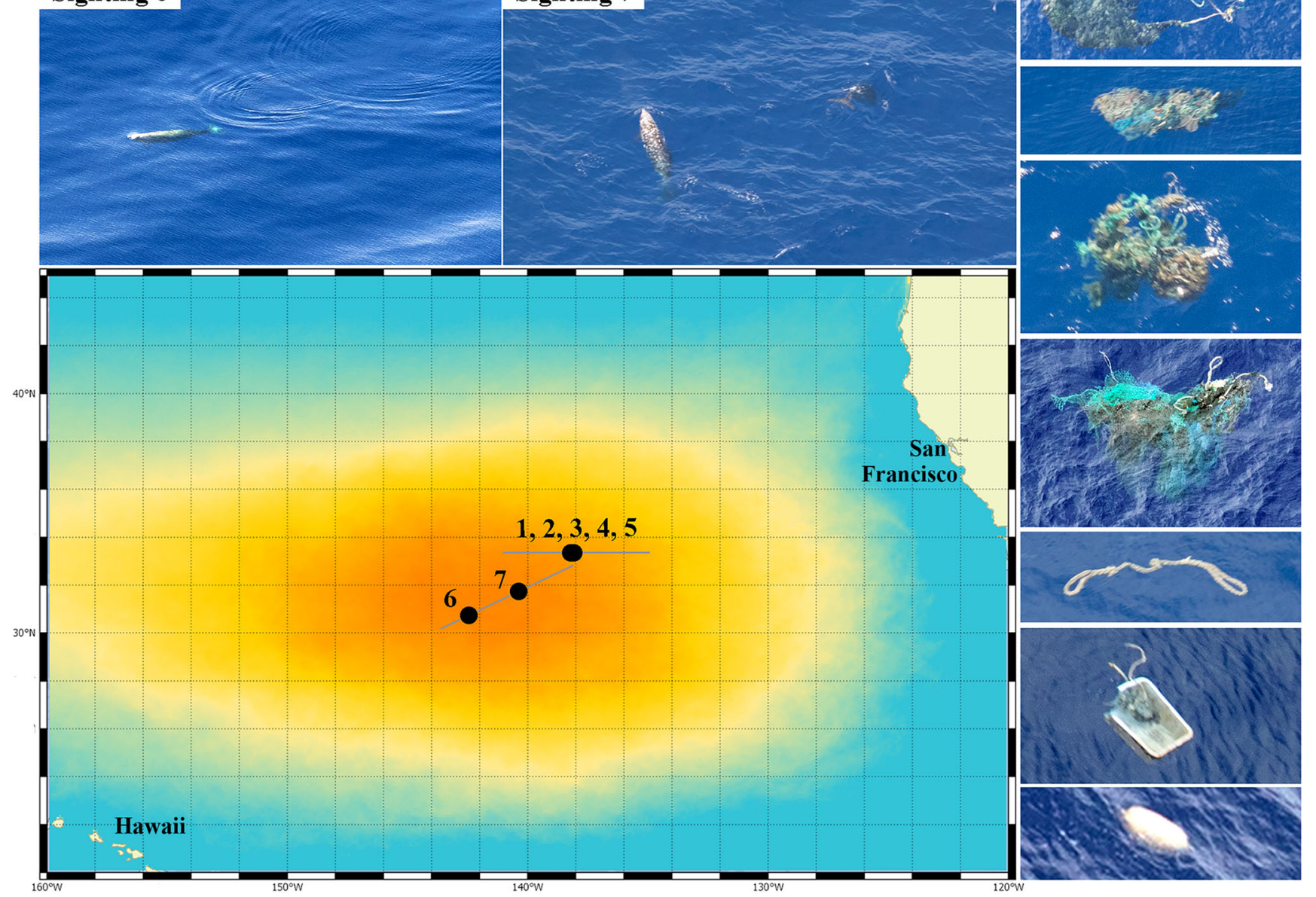

Fig. 1 Cetaceans and ocean plastics within the Great Pacific Garbage Patch. In the map, background colour levels represent predicted plastic pollution gradient (red = highest levels, blue = lowest levels; Lebreton et al. 2012); grey lines show the survey transects ( $\sim 665 \mathrm{~km}$ each) and black dots indicate locations of our seven cetacean sightings (see Table 1 for details). Photographs above the map show some of the cetaceans observed in this study: sperm whales (sighting 2, and sighting 3 ) and beaked whales (sighting 6, and sighting 7); red circles in sighting 3 indicate debris locations. Photographs in the right side of the figure give examples of debris types sighted: 'ghostnets', ropes, crates and buoys 
They were unable to hear or see each other. Each observer was paired with a data recorder, with communications occurring via David Clarke radio headsets and wind-protected microphones. These radio transmissions were recorded on separate channels using a multi-track audio recorder. Observers were equipped with polarised sunglasses, a Canon 7D Mark II DSLR camera with a 70-300 mm F/4-5.6 EF USM lens and a Canon $10 \times 30$ IS II image-stabilised binoculars. Data recorders had a laptop with the positioning software VADAR (developed by Dr. Hendrik Kniest at the University of Newcastle, NSW, Australia) and documented start and end times of surveys, as well as sightings and environmental information in real time.

Observers continuously scanned the ocean surface within their field of view for debris (the main focus), and cetaceans were recorded when opportunistically sighted. Cetacean identification was achieved by combining in situ observations with post-survey examination of photographs. Debris sampling prioritised objects estimated to be larger than $0.5 \mathrm{~m}$ in length. They were classified into the following types: net - a single fishing net or a group of fishing nets bundled tightly together; rope-long cylindrical objects around $15 \mathrm{~cm}$ thick; container-rectangular and bright objects, such as fishing crates and drums; buoy/lid — rounded bright objects that could be either a lid or a buoy; other - objects that could be identified but did not belong to any of our object types; and unknown — objects that were clearly debris but whose object type could not be identified (Lebreton et al. 2018). Declination angles from the horizon were recorded for large debris, but not for cetaceans. A more detailed description of our visual survey method is found in Salgado Kent et al. (2017).

We also fitted three sensors to the aircraft: a short-wave infrared imager (Garaba et al. 2018), a Lidar System (Feygels et al. 2017) and RGB CS-4800i 16MP frame camera. While in survey mode, these sensors imaged the ocean at NADIR position from the open cargo door (rear of aircraft). There was no overlap between the observers' viewing areas and the region sampled by these sensors (below the aircraft). The RGB camera took a photograph every second of the survey. All photographs were subsequently transformed into georeferenced single-frame mosaics of $\sim 360 \mathrm{~m}$ across track and $\sim 240 \mathrm{~m}$ along track, at a $\sim 0.1 \mathrm{~m}$ pixel resolution and $25 \%$ forward overlap. These RGB mosaics covered a total sea surface area of $311 \mathrm{~km}^{2}$ and were inspected post-survey by two observers trained to detect and characterise debris and wildlife on an HD monitor (Samsung LU28E590DS/XY). Taking a conservative approach, we only considered items that could be confidently identified as debris or wildlife. For each sighting, position (latitude, longitude), length and type of object were recorded. For debris, we used the same classification as used by the in situ observers: net, rope, container, buoy/lid, other and unknown (Lebreton et al. 2018). Some of the objects detected in the RGB mosaics were further explored using the simultaneously collected LIDAR and hyperspectral data. Hyperspectral imagery was captured using an ITRES SASI600 push broom line scanning imager with 100 wavebands in the SWIR, ranging from 950 to $2450 \mathrm{~nm}$, at $15 \mathrm{~nm}$ spectral resolution and $0.5 \mathrm{~m}$ across $\times 1.2 \mathrm{~m}$ along track spatial resolution (Garaba et al. 2018). The CZMIL LIDAR used in this study is a hybrid scanned-flash system employing a $10-\mathrm{kHz}$ laser and circular scanner, with a segmented detector enabling simultaneous recording of high-density data from a single laser (Feygels et al. 2017).

\section{Results}

We observed at least 14 cetacean individuals (Table 1; Fig. 1) and registered 1280 large plastics while surveying the GPGP region. This equates to a ratio of approximately 90 objects per specimen sighted. Ocean plastics were occasionally seen in close proximity (i.e., a few meters) to the animals (see Fig. 1b) which were not evenly distributed along the transects, with the first 5 out of 7 sightings occurring within a short period of time. All but one sighting (the fifth sighting) was photographed, but the quality of the images varied for species identification purposes.

The first cetacean sighting was a group of at least four small odontocetes. Sighting two comprised three sperm whales (Physeter macrocephalus) - a mother, calf and an escort-detected in the RGB mosaics, LIDAR data and hyperspectral imagery (Fig. 2). Sighting three was a large dark-coloured whale, possibly a sperm whale. The fourth sighting was a single whale that was recorded as "relatively large" in size. The fifth sighting (and last cetacean sighting of the first flight) included at least two baleen whales (suborder Mysticeti) identified by the observation of two large blows with shapes consistent with those produced by the double blowholes of baleen whales. The sixth sighting (first cetacean sighting of the second flight) was of a beaked whale (family Ziphiidae). The seventh and final sighting was of two beaked whales. Although the observed beaked whales were not identified to species, some features were similar to Cuvier's beaked whale (Ziphius calvirostris). Nonetheless, our two beaked whale sightings may have been of different species.

We recorded 969 debris items larger than $50 \mathrm{~cm}$ in the RGB mosaics (Lebreton et al. 2018) and logged 311 objects (mostly $>50 \mathrm{~cm}$ ) in situ during visual surveys (Salgado Kent et al. 2017). These plastics varied in size, colour and type. Most of them could not be clearly identified, with the frequency of occurrence (FO) of type 'unknown' equal to $51 \%$ for visual surveys, and $32 \%$ for RGB mosaics. Post-processing of closeup photographs taken by the observers indicate these unknown pieces were mostly fragmented plastic. Of the objects for which type was identified, the most common ones were 
Table 1 Cetacean sightings of this study. With the exception of sighting 2 (registered in our geo-referenced RGB mosaics), sighting positions are the aircraft's locations when observers made the cetacean record.
Assuming detectability is similar to what we experienced with $>50 \mathrm{~cm}$ debris (Salgado Kent et al. 2017), it is very likely that the cetaceans were within $900 \mathrm{~m}$ of the locations reported here

\begin{tabular}{llll}
\hline No. & Latitude & Longitude & Description \\
\hline 1 & $33^{\circ} 29^{\prime} 55.57^{\prime \prime} \mathrm{N}$ & $138^{\circ} 10^{\prime} 53.37^{\prime \prime} \mathrm{W}$ & At least four small odontocetes \\
2 & $33^{\circ} 30^{\prime} 1.80^{\prime \prime} \mathrm{N}$ & $138^{\circ} 10^{\prime} 20.52^{\prime \prime} \mathrm{W}$ & $\begin{array}{c}\text { Three sperm whales: mother } \\
(11.3 \mathrm{~m} \text { in length), calf }(4.5 \mathrm{~m}) \text { and escort }(10.5 \mathrm{~m})\end{array}$ \\
3 & $33^{\circ} 29^{\prime} 51.41^{\prime \prime} \mathrm{N}$ & Large dark-coloured whale, likely a sperm whale \\
4 & $33^{\circ} 29^{\prime} 48.39^{\prime \prime} \mathrm{N}$ & $138^{\circ} 9^{\prime} 42.78^{\prime \prime} \mathrm{W}$ & Single large whale \\
5 & $33^{\circ} 29^{\prime} 50.83^{\prime \prime} \mathrm{N}$ & $138^{\circ} 8^{\prime} 32.33^{\prime \prime} \mathrm{W}$ & Two baleen whales \\
6 & $30^{\circ} 48^{\prime} 25.10^{\prime \prime} \mathrm{N}$ & $138^{\circ} 6^{\prime} 17.03^{\prime \prime} \mathrm{W}$ & Single beaked whale \\
7 & $31^{\circ} 50^{\prime} 42.66^{\prime \prime} \mathrm{N}$ & $142^{\circ} 24^{\prime} 52.28^{\prime \prime} \mathrm{W}$ & Two beaked whales \\
\hline
\end{tabular}

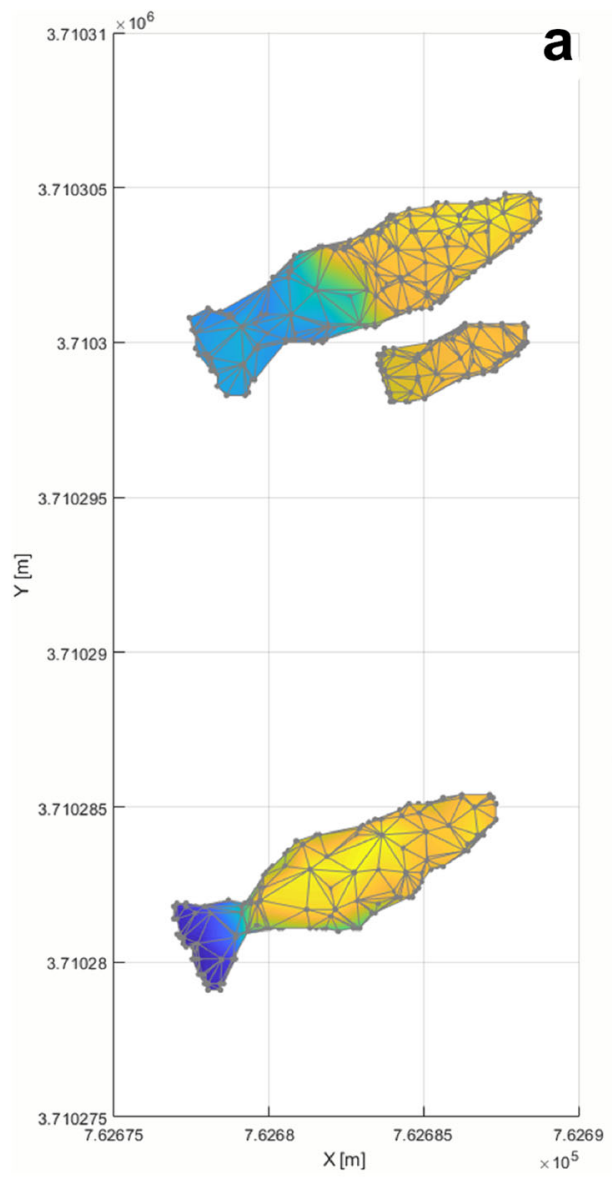

Fig. 2 Sperm whales as detected by LIDAR and SWIR sensors. These same whales were also recorded in our RGB mosaic (see Fig. 1, sighting 2). a, b Three-dimensional model of the whales created from LIDAR returns. Colours indicate the relative depth of the animals' body, with warmer colours showing portions closer to the sea surface. All axes are in meters, with $\mathrm{Z}$ values showing ellipsoid height; c Spectral at-sensor
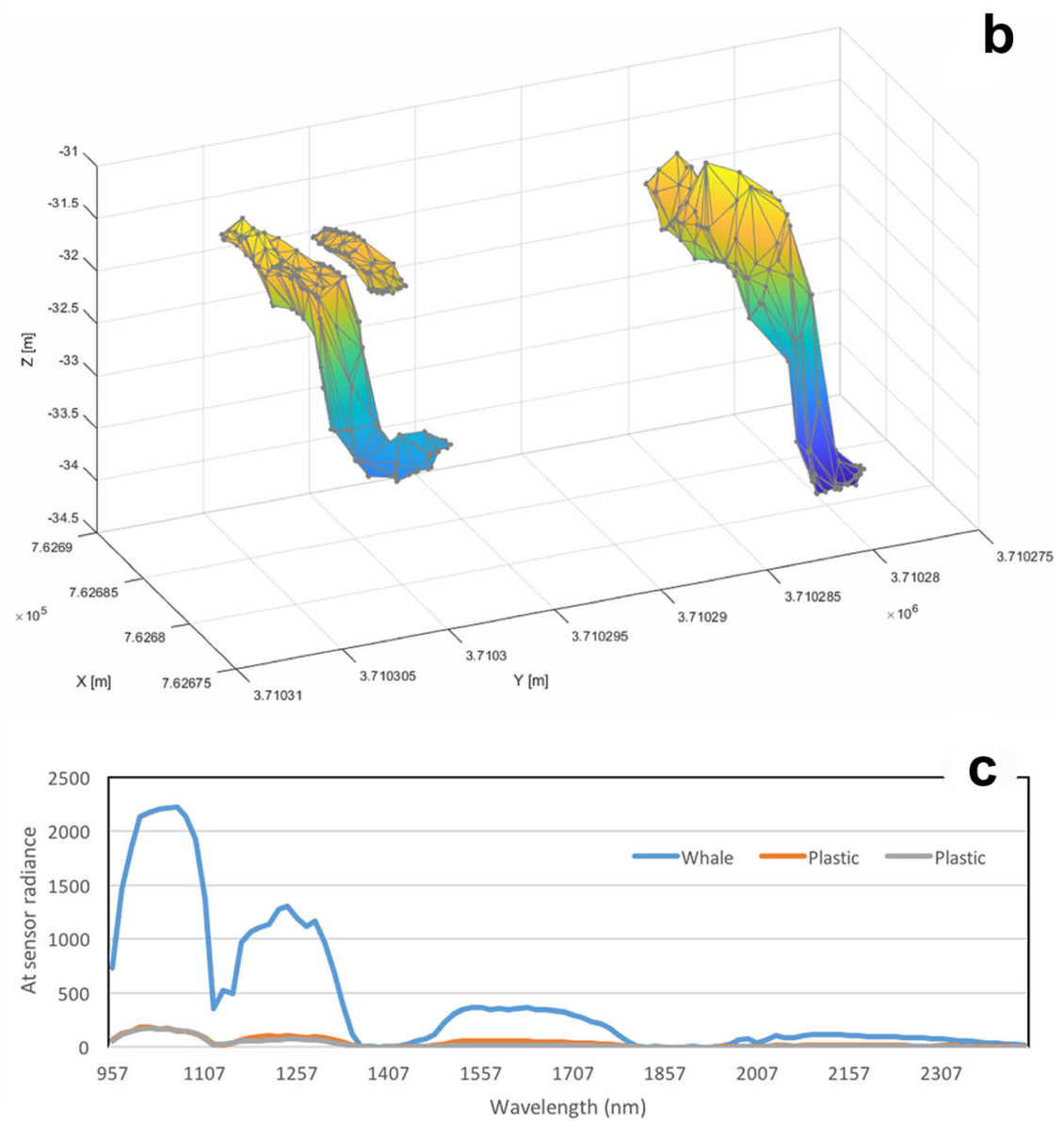

radiance $\left(\mu \mathrm{W}^{-2} \mathrm{~cm}^{-2} \mathrm{sr}^{-1} \mathrm{~nm}^{-1} ; 950\right.$ to $\left.2450 \mathrm{~nm}\right)$ of whales and ocean plastics, as recorded by our SWIR imager. Note the unique shape and magnitude of the radiance of whales when compared to plastics. Pixels with seawater had negligible radiance $\left(<30 \mu \mathrm{W}^{-2} \mathrm{~cm}^{-2} \mathrm{sr}^{-1} \mathrm{~nm}^{-1}\right)$, except when sun glint was present 
fishing nets ( $\mathrm{FO}=31 \%$ for visual surveys, $32 \%$ for RGB mosaics). Other debris types included containers (FO $=6 \%$ and $18 \%$ for visual and RGB mosaics, respectively), buoys/lids $(\mathrm{FO}=4 \%$ and $9 \%)$ and ropes $(\mathrm{FO}=9 \%$ and $6 \%)$.

\section{Discussion}

Our study demonstrates that the GPGP area is used by multiple cetacean species, including sperm and beaked whales. The occurrence of a sperm whale mother and calf pair shows that individuals are using the region at various life stages. Sperm whale calves are born at around $4 \mathrm{~m}$ length (Boyd et al. 1999), indicating the observed calf ( $4.5 \mathrm{~m}$ in length) was very young. Cetacean population structures and movement patterns in this area are not well known (e.g., Whitehead 2009; Mesnick et al. 2011), and it is unclear whether sperm whales migrate through the GPGP, are always present or both. Beaked whales (Ziphiidae) are widely distributed but remain one of the least researched families. They only spend a small proportion of their time at the surface (Shearer et al. 2019), so the number of animals reported in this study represents a minimum present in the area surveyed.

Our sightings of numerous ocean plastics of a wide range of sizes suggest that cetaceans within the GPGP are likely impacted by plastic pollution, either through ingestion and/or entanglement interactions with debris items. Plastics are known to be ingested by cetaceans, with whales mistaking them for food and/or consuming them incidentally while feeding on prey organisms that are aggregated near plastics or that contain synthetic particles in their digestive tracts. Jacobsen et al. (2010) examined sperm whales stranded along the Californian coast and found that the cause of death was gastric impaction due to ingestion of large amounts of floating plastic debris such as fishing nets and ropes. They suggested that the ingestion of these plastics occurred within the North Pacific subtropical gyre, which is the region studied here. Beaked whales have a reduced dentition, narrow gape and suction-feeding behaviour that restricts prey size consumed (MacLeod 2014). To meet energy requirements while foraging on prey that is small relative to their body size, they spend the majority of their time foraging (MacLeod et al. 2003; MacLeod 2014) and are therefore likely to be feeding within the GPGP. Plastics are common in the stomach contents of many species of stranded beaked whales and have been reported as a cause of death (e.g. Walker and Coe 1989; Secchi and Zarzur 1999; Simmonds 2012; Kaladharan et al. 2014; Lusher et al. 2015). Microplastics $(<5 \mathrm{~mm})$ have also been found in the gastrointestinal tracts of baleen whales (Fossi et al. 2012; Besseling et al. 2015). Their filter feeding behaviour, i.e. either skim feeding or lunge feeding, make them particularly susceptible to accidently consuming small synthetic particles that may pose a chemical threat to them (Fossi et al. 2014; Chen et al. 2017).
We observed many large debris items that pose an entanglement risk to marine megafauna, with lost or discarded fishing nets (the so-called ghostnets) being the most frequently observed type of debris in our survey. Ghostnets are a particularly concerning type of ocean plastics as they can continuously trap marine life in a process known as 'ghost fishing' (Laist 1987). The durability and strength of entangled plastics can cause chronic injury, starvation and general debilitation that may be fatal (Kraus et al. 2005; Kemper et al. 2008; Moore 2014). Entanglement issues have been recorded in many species of marine mammals, including sperm whales (Haase and Felix 1994), which are listed on the IUCN Red List as 'vulnerable' (Taylor et al. 2008). We also suggest that the occurrence of large ocean plastics within the GPGP could be affecting the behaviour and distribution of some animals. For example, many of the observed plastics were of sufficient size to act as fish aggregating devices (FADs; Stelfox et al. 2016). As such, they may attract feeding cetaceans and increase their risk of plastic entanglement and ingestion.

It is important to highlight that the primary aim of our aerial survey was to better quantify and characterise ocean plastics. Therefore, visual survey observers may have missed some marine mammals, as search effort was focused on floating objects, and the height and speed of the aircraft were not optimal for maximising cetacean detections. Furthermore, environmental conditions degraded detectability within some regions of the survey (e.g. intense sun glare, cloud below the aircraft). GPGP surveys with an optimised protocol for wildlife detection are necessary to acquire abundance estimates and density distributions of marine mammals within and around this area. Despite constraints, this study demonstrates that several cetacean species occur in the GPGP, thus supporting the need for further research to evaluate the risk of this plastic pollution hotspot to marine mammals.

Acknowledgments The authors thank The Ocean Cleanup donors and supporters. We also acknowledge International Air Response, Teledyne Optech, NOARC and ITRES for their partnership in the execution of the Aerial Expedition project, and Google for Moffett Airfield sponsorship. A special thanks goes to Bob Marthouse and Jen Aitkin for the collection and creation of the RGB mosaics and analyses of sensor data. We also thank Rick Martini, Anna Schwartz and Laurent Lebreton for support with logistics and survey planning; Kim Noble, Sara Niksic, Florent Beauverd and Taylor Swift for assistance with the field work; Sara Hajbane, Igor Carneiro, and Tiago Gandra for post-processing of RGB mosaics and Hendrik Kniest, from the University of Newcastle, for adapting the software VADAR to this survey.

Author contributions SEG, CSK, BS and JR designed the study; SEG, CSK, DM and LF performed the visual surveys; SEG, CSK, DM and LF identified the marine mammals sighted; SEG and JR wrote the manuscript; JR prepared the figures and table. All the authors reviewed the manuscript and approved the final article. 


\section{Compliance with ethical standards}

Conflict of interest The authors declare that they have no conflicts of interest.

Ethical approval All applicable international, national, and/or institutional guidelines for the care and use of animals were followed by the authors.

Sampling and field studies All necessary permits for sampling and observational field studies have been obtained by the authors from the competent authorities and are mentioned in the acknowledgements, if applicable.

\section{Data availability Our manuscript has no associated data.}

Open Access This article is distributed under the terms of the Creative Commons Attribution 4.0 International License (http:// creativecommons.org/licenses/by/4.0/), which permits unrestricted use, distribution, and reproduction in any medium, provided you give appropriate credit to the original author(s) and the source, provide a link to the Creative Commons license, and indicate if changes were made.

\section{References}

Baulch S, Perry C (2014) Evaluating the impacts of marine debris on cetaceans. Mar Pollut Bull 80:210-221

Besseling E, Foekema EM, Van Franeker JA, Leopold MF, Kühn S, Bravo Rebolledo EL, Heße E, Mielke L, IJzer J, Kamminga P, Koelmans AA (2015) Microplastic in a macro filter feeder: humpback whale Megaptera novaeangliae. Mar Pollut Bull 95(1):248_252

Boyd IL, Lockyer C, Marsh HD (1999) Reproduction in marine mammals. In: Reynold JE, Rommel SA (eds) Biology of marine mammals. Melbourne University Press, Carlton South, p 261

Chen Q, Reisser J, Cunsolo S, Kwadijk C, Kotterman M, Proietti M, Slat B, Ferrari FF, Schwarz A, Levivier A, Yin D, Hollert H, Koelmans AA (2017) Pollutants in plastics within the North Pacific subtropical gyre. Environ Sci Technol 52:446-456

Chu S, Wang J, Leong G, Woodward LA, Letcher RJ, Li QX (2015) Perfluoroalkyl sulfonates and carboxylic acids in liver, muscle and adipose tissues of black-footed albatross (Phoebastria nigripes) from Midway Island, North Pacific Ocean. Chemosphere 138:60 66

Eriksen M, Lebreton LCM, Carson HS, Thiel M, Moore CJ, Borerro JC, Galgani F, Ryan PG, Reisser J (2014) Plastic pollution in the world's oceans: more than 5 trillion plastic pieces weighing over 250,000 tons afloat at sea. PLoS One 9(12)

Feygels V, Aitken J, Ramnath V, Duong H, Marthouse R, Smith B, Clark N, Renz E, Reisser J, Kopilevich Y (2017) Coastal zone mapping and imaging Lidar (CZMIL) participation in the ocean cleanup's aerial expedition project. Proc of Oceans 17 conference, Anchorage, Alaska, Sep 18-21, 2017

Fossi MC, Panti C, Guerranti C, Coppola D, Giannetti M, Marsili L, Minutoli R (2012) Are baleen whales exposed to the threat of microplastics? A case study of the Mediterranean fin whale (Balaenoptera physalus). Mar Pollut Bull 64:2374-2379

Fossi MC, Coppola D, Baini M, Giannetti M, Guerranti C, Marsili L, Panti C, de Sabata E, Clò S (2014) Large filter feeding marine organisms as indicators of microplastic in the pelagic environment: the case studies of the Mediterranean basking shark (Cetorhinus maximus) and fin whale (Balaenoptera physalus). Mar Environ Res 100:17-24

Garaba SP, Aitken J, Slat B, Dierssen HM, Lebreton L, Zielinski O, Reisser J (2018) Sensing ocean plastics with an airborne hyperspectral shortwave infrared imager. Environ Sci Technol 52: 11699-11707

Haase B, Felix F (1994) A note on the incidental mortality of sperm whales (Physeter macrocephalus) in Ecuador. Rep Int Whaling Comm Spec Issue 15:481-484

Jacobsen JK, Massey L, Gulland F (2010) Fatal ingestion of floating net debris by two sperm whales (Physeter macrocephalus). Mar Pollut Bull 60:765-767

Kaiser J (2010) The dirt on ocean garbage patches. Science 328(5985): 1506

Kaladharan EP, Asokan PK, Koya M, Bhint HM (2014) Plastic debris in the stomach of a Longman's beaked whale, Indopacetus pacificus (Longman 1926) stranded off Sutrapada, Veraval, Saurashtra coast, India. J Mar Biol Assoc India 56(2):92-94

Kemper CM, Coughran D, Warneke R, Pirzl R, Watson M, Gales R, Gibbs SE (2008) Southern right whale (Eubalaena australis) mortalities and human interactions in Australia, 1950-2006. J Cetacean Res Manag 10:1-8

Kraus SD, Brown MW, Caswell H, Clark CW, Fujiwara M, Hamilton PK, Kenney RD, Knowlton AR, Landry S, Mayo CA (2005) North Atlantic right whales in crisis. Science 309:561-562

Laist DW (1987) Overview of the biological effects of lost and discarded plastic debris in the marine environment. Mar Pollut Bull 18:319326

Laist DW (1997) Impacts of marine debris: entanglement of marine life in marine debris including a comprehensive list of species with entanglement and ingestion records. In: Coe JM, Rogers DB (eds) Mar Debris, Springer Series on Environmental Management. Springer, New York, pp 99-413

Lebreton L, Greer SD, Borrero JC (2012) Numerical modelling of floating debris in the world's oceans. Mar Pollut Bull 64: 653-661

Lebreton L, Slat B, Ferrari F, Sainte-Rose B, Aitken J, Marthouse R, Hajbane S, Cunsolo S, Schwarz A, Levivier A, Noble K, Debeljak P, Maral H, Schoeneich-Argent R, Brambini R, Reisser J (2018) Evidence that the Great Pacific garbage patch is rapidly accumulating plastic. Sci Rep 8:466

Lusher AL, Hernandez-Milian G, O'Brien JM, Berrow S, O'Connor I, Officer RA (2015) Microplastic and macroplastic ingestion by a deep diving, oceanic cetacean: the True's beaked whale Mesoplodon mirus. Environ Pollut 199:185-191

MacLeod CD (2014) Family Ziphiidae (beaked whales). In: Wilson DE, Mittermeier RSA (eds) Handbook of the mammals of the world, Sea mammals, vol 4. Lynx Editions, Barcelona, pp 326-357

MacLeod CD, Santos MB, Pierce GJ (2003) Review of data on diets of beaked whales: evidence of niche separation and geographic segregation. J Mar Biol Assoc UK 83:651-665

Mesnick SL, Taylor BL, Archer FI, Martien KK, Escorza Treviño S, Hancock-Hanser BL, Moreno Medina SC, Pease VL, Robertson KM, Straley JM, Baird RW, Calambokidis J, Schorr GS, Wade P, Burkanov V, Lunsford CR, Rendell L, Morin PA (2011) Sperm whale population structure in the eastern and central North Pacific inferred by the use of single nucleotide polymorphisms (SNPs), microsatellites and mitochondrial DNA. Mol Ecol Resour 11(Suppl. 1):278-298

Moore MJ (2014) How we all kill whales. ICES J Mar Sci 77:760-763

Page B, McKenzie J, McIntosh R, Baylis A, Morrissey A, Calvert N, Haase T, Berris M, Dowie D, Shaughnessy PD (2004) Entanglement of Australian sea lions and New Zealand fur seals in lost fishing gear and other marine debris before and after government and industry attempts to reduce the problem. Mar Pollut Bull 49:33-42 
Salgado Kent C, Reisser J, Gibbs SE, Fouda L, Morales D, Kniest H (2017) Quantification of medium and large debris in the Great Pacific garbage patch using visual observations from aerial surveys. Technical Report

Secchi ER, Zarzur S (1999) Plastic debris ingested by a Blainville's beaked whale, Mesoplodon densirostris, washed ashore in Brazil. J Mar Biol Assoc UK Aquat Mamm 25(1):21-24

Shearer JM, Quick NJ, Cioffi WR, Baird RW, Webster DL, Foley DL, Swaim ZT, Waples DM, Bell JT, Read AJ (2019) Diving behaviour of Curvier's beaked whales (Ziphius cavirostris) off Cape Hatteras, North Carolina. R Soc Open Sci 6: 181728

Simmonds MP (2012) Cetaceans and marine debris: the great unknown. J Mar Biol 2012:684279

Stelfox M, Hudgins J, Sweet M (2016) A review of ghost gear entanglement amongst marine mammals, reptiles and elasmobranchs. Mar Pollut Bull 111:6-17

Taylor BL, Baird R, Barlow J, Dawson SM, Ford J, Mead JG, Notarbartolo di Sciara G, Wade P, Pitman RL (2008) Physeter macrocephalus The IUCN Red List of Threatened Species 2008. Available at www.iucnredlist.org/. Accessed 12 Dec 2017

Walker WA, Coe JM (1989) Survey of marine debris ingestion by odontocete cetaceans. In: Shomura RS, Godfrey HL (eds) Proceedings of the Second International Conference on Marine Debris, 2-7 April 1989. U.S. Department of Commerce, NOAA Technical Memo. NNFS. NOM-TH-NHFS-SWFSC-154. Honolulu, Hawaii, pp 747-774

Whitehead H (2009) Sperm whales: Physeter macrocephalus. In: Perrin WF, Würsig B, Thewissen JGM (eds) Encyclopedia of marine mammals, 2nd edn. Academic Press, San Diego, pp 1091-1097

Publisher's note Springer Nature remains neutral with regard to jurisdictional claims in published maps and institutional affiliations. 